\title{
Scolelepis (Polychaeta: Spionidae) from the Brazilian coast with a diagnosis of the genus
}

\author{
Marcelo Borges Rocha ${ }^{1,2} \&$ Paulo Cesar de Paiva ${ }^{1}$
}

\author{
${ }^{1}$ Departamento de Zoologia, Instituto de Ciências Biológicas, Universidade Federal do Rio de Janeiro. 21941-590 Rio de \\ Janeiro, RJ, Brazil. \\ ${ }^{2}$ Centro Federal de Educação Tecnológica Celso Suckow da Fonseca. 20271-110 Rio de Janeiro, RJ, Brazil. \\ E-mail: rochamarcelo36@yahoo.com.br
}

\begin{abstract}
Five species of Scolelepis have been reported for the Brazilian coast. This study raises this number, with two new records: S. acuta Treadwell, 1914, originally from Eastern Pacific, and Scolelepis andradei Delgado-Blas, Díaz \& LiñeroArana, 2009, from the Caribbean Sea. Furthermore, two species were found to have an expanded geographic range along the Brazilian coast: Scolelepis lighti Delgado-Blas, 2006 and Scolelepis goodbodyi Jones, 1962.
\end{abstract}

KEY WORDS. Morphology; Scolelepis acuta; Scolelepis andradei; systematics; taxonomy.

Species of Scolelepis are bathymetrically widespread in almost all types of substrates (BLAKE 1996), and are the dominant genus of Spionidae in sand-beaches and other near-shore areas.

Scolelepis was revised by MAcioleK (1987), who based the description of the genus on the morphology of the hooded hooks and proposed the establishment of two subgenera, Scolelepis and Parascolelepis. Species with uni-, bi- or tridentate hooks should be included within the subgenus Scolelepis Blainville, 1828, whereas those with multidentate hooks are included within Parascolelepis Maciolek, 1987. This division into two subgenera has been adopted by several authors (e.g., BlaKe 1996, DelgadoBlas 2006, Delgado-Blas et al. 2009). Nevertheless, Williams (2007), considering the results of the phylogenetic analysis of BLAKE \& ARNofsKy (1999) and BlaKe (2006), adopted the generic rank for Scolelepis and Parascolelepis, a procedure followed here.

Currently, 45 species of Scolelepis and 12 of Parascolelepis are recognized worldwide (Delgado-Blas 2006, Delgado-Blas et al. 2009).

So far, five species of Scolelepis and two of Parascolelepis are recorded for the Brazilian coast: Scolelepis chilensis Hartmann-Schröder, 1962 (MacCord \& Amaral 2005); S. goodbodyi Jones, 1962 (MACCORD \& AMARAL 2005); S. squamata Müller, 1806; S. lighti Delgado-Blas, 2006 (SANTos et al. 2008); S. gaucha Orensanz \& Gianuca, 1974; Parascolelepis texana Foster, 1971 (AMARAL et al. 2012) and P. quinquedentata Hartmann Schröder, 1965 (LaNa et al. 2006). The overlap of characteristics among different species, and the great variability within and among populations have lead to difficulties in species diagnostics, increasing the risk of misidentification. For example, Bolivar \& LANa (1986) and MACCord \& AMARaL (2005), observing the considerable morphological variability in the material referred to as $S$. squamata, a widely recorded species, proposed that it might be considered as a species complex. Similar variability has been reported in other studies. ZHou et al. (2009), after studying Scolelepis species on northern Chinese beaches, pointed out that, after carefully reviewing the material previously described as $S$. squamata, they were describing it as a new species, Scolelepis daphoinos.

Delgado-Blas (2006), studying the genus in the Gran Caribbean region, revalidated four species based on the shape of the notopodial lamellae, viz., S. goodbodyi (Jones, 1962), $S$. minuta Treadwell, 1939, S. acuta (Treadwell, 1914) and S. agilis Verrill, 1873, thereby removing them from synonymy with $S$. squamata Müller, 1806. Furthermore, Foster (1971) and Light (1977) also discussed the considerable morphological variation of $S$. squamata, for instance, the presence and degree of development of a notch on the median neuropodia, and the presence or absence of notopodial hooded hooks within a single population of the species. Hence there is a perceivable difficulty in establishing the identity of this particular species, and also of the genus Scolelepis.

In this study, specimens of Scolelepis collected off the Brazilian coast were examined. The present paper is a contribution to the knowledge of the genus in Brazil. It presents new records of two species, Scolelepis acuta (Treadwell, 1914) and $S$. andradei Delgado-Blas, Díaz \& Liñero-Arana, 2009, and evidence of an expanded range for two species: S. lighti Delgado-Blas, 2006 and S. goodbodyi Jones, 1962.

\section{MATERIAL AND METHODS}

The specimens analyzed in this study were collected from 15 beaches along the coast of Brazil. Sediment samples, collected with a shovel, were processed with $0.5 \mathrm{~mm}$ mesh sieves. 
Before examination, the worms were anesthetized with isotonic magnesium chloride for 20 minutes; while some were fixed in $10 \%$ formalin and transferred to $70 \%$ ethanol, others were preserved directly in $92 \%$ ethanol. A total of 804 specimens were examined under a ZEISS Stemi stereomicroscope.

Illustrations of the external morphology were prepared under a camera lucida coupled to a stereomicroscope and optical microscopes. Following this, observations were made with a Scanning Electron Microscope (SEM) (Jeol JSM 6390 LV) at the Instituto de Biofísica, Universidade Federal do Rio de Janeiro and the Museu Nacional, UFRJ. A $40 \mathrm{~Hz}$ sonicator was used for removing the hoods from the hooks. The samples were transferred from $70 \%$ ethanol to distilled water for an hour, in order to allow the ethanol in the tissues to be replaced with water. After cutting the samples into pieces, they were sonicated in distilled water for 40 seconds, after which the resultant fragments were dehydrated with an ethanol series of 50, 70, 80, 90 and 100\%, leaving 10 minutes for each concentration. The critical point was performed with a CPD 030 (Leica), and gold metallization with Balzers equipment. All specimens obtained were deposited in the polychaete collection of the Departamento de Zoologia, Instituto de Biologia, Universidade Federal do Rio de Janeiro (IBUFRJ).

\section{RESULTS}

The morphological characters that proved to be the most relevant in identifying the species described in this study were those related to the shape of the prostomium, parapodia of chaetiger 1, branchiae, the shape of the neuropodial postchaetal lamellae, and shape and distribution of the hooks (BLAKE 1983, Maciolek 1987, Imajima 1992, Eibye-Jacobsen \& Soares 2000, Delgado-Blas 2006, Williams 2007, Zhou et al. 2009, DelgadoBlas et al. 2009). Removing the hoods from the hooks before SEM observations allowed for a better visualization of the distribution and number of teeth in the hooks, and their variability among species was evaluated.

\section{Spionidae Grube, 1850 Scolelepis Blainville, 1828}

Diagnosis: Prostomium elongated with a cone-shaped or triangular anterior, extending posteriorly as a fairly conspicuous caruncle in the dorsal of the body. Occipital tentacle, present or absent. Peristomium well-developed, involving the prostomium laterally and ventrally with lateral wings. Proboscis eversible. Branchiae present from chaetiger 2 to the end of the body. Branchiae ranging from completely fused to notopodial lamellae to partially fused with the distal portion free in anteriormost segments. Simple capillary chaetae in both rami (noto and neuropodia). Median and posterior neuropodia have hooded hooks with a bluntly rounded main fang surmounted by one or two smaller apical teeth placed side by side above the main fang. Notopodia with or without hooded hooks. Pygidium thick pad shaped or with a multilobated ventral appendage; anus dorsal.

\section{Scolelepis goodbodyi (Jones, 1962)}

Nerinides goodbodyi Jones, 1962: 187, figs 66-68.

Scolelepis goodbodyi; Delgado-Blas, 2006: 83, fig. 4.

Scolelepis goodbodyi; Rocha, Radashevsky \& Paiva, 2009: 102, fig.1 (in part).

Material examined: 363 specimens: Brazil, Ceará: Fortaleza (Dois Coqueiros beach, $34^{\circ} 30^{\prime} \mathrm{S}, 38^{\circ} 29^{\prime} \mathrm{W}$ ), 30 specimens, 23/ VII/2005, IBUFRJ-1253. Rio de Janeiro: Rio de Janeiro (Flamengo beach, $\left.22^{\circ} 55^{\prime} \mathrm{S}, 43^{\circ} 10^{\prime} \mathrm{W}\right), 41$ specimens, 15/VI/2005, IBUFRJ0730. Rio de Janeiro: Ilha Grande Bay (Dois Rios beach, $23^{\circ} 11^{\prime} \mathrm{S}$, $\left.44^{\circ} 11^{\prime} \mathrm{W}\right), 10$ specimens, 10/VII/2000, IBUFRJ-0736. Rio de Janeiro: Sepetiba Bay (Marambaia Island, $22^{\circ} 51 \mathrm{~S}, 43^{\circ} 57^{\prime} \mathrm{W}$ ), 40 specimens, 12/I/2004, IBUFRJ-1256. São Paulo: São Sebastião (Barequeçaba beach, $23^{\circ} 50^{\prime} \mathrm{S}, 4^{\circ} 29^{\prime} \mathrm{W}$ ), 17 specimens, 25/X/2002, IBUFRJ1255. São Paulo: Ubatuba (Picinguaba beach, $23^{\circ} 22^{\prime} \mathrm{S}, 44^{\circ} 50^{\prime} \mathrm{W}$ ), 67 specimens, 19/XI/2005, IBUFRJ-1254. São Paulo: Santos (Boqueirão beach, $38^{\circ} 34^{\prime} \mathrm{S}, 38^{\circ} 52^{\prime} \mathrm{W}$ ), 63 specimens, $12 / \mathrm{X} / 2007$, IBUFRJ-1252. Paraná: Pontal do Paraná (Pontal do Sul beach, $\left.23^{\circ} 34^{\prime} \mathrm{S}, 48^{\circ} 20^{\prime} \mathrm{W}\right), 65$ specimens, 09/IX/2009, IBUFRJ-1251. Santa Catarina: Florianópolis Island (Barra da Lagoa, 27³4"S, $\left.48^{\circ} 25^{\prime} \mathrm{W}\right), 30$ specimens, 15/X/2010, IBUFRJ-1251.

Remarks: The material, here referred to $S$. goodbodyi, is very similar to that originally described by Jones (1962) and DeLgadoBlas (2006). Although differing in the presence of bilobed neuropodial postchaetal lamellae (in chaetiger 20 in the original description and between chaetigers 16-19 in our material). Previous records of this species on the Brazilian Coast were restricted to the southern coast, but now the species distribution is extended to the north-eastern coast (Ceará), filling a distribution gap given it already occurred in the Caribbean Sea.

Distribution: Caribbean Sea: Jamaica (Port Henderson, Green Bay); Atlantic Ocean: Brazil (northern and southern coast).

\section{Scolelepis chilensis (Hartmann-Schröder, 1962)}

Nerine cirratulus chilensis Hartmann-Schröder, 1962: 142-144, figs 179-182.

Scolelepis chilensis; Blake, 1983: 207, fig. 2.

?Scolelepis squamata; Bolívar \& Lana, 1986 (in part)

Scolelepis chilensis; Rocha, Radashevsky \& Paiva, 2009: 105, fig. 3.

Material examined: 188 specimens: Brazil, Rio de Janeiro: Rio de Janeiro (Flamengo beach, $22^{\circ} 55^{\prime} \mathrm{S}, 43^{\circ} 10^{\prime} \mathrm{W}$ ), 62 specimens, 07/VI/2005, IBUFRJ-0731. Rio de Janeiro: Armação dos Búzios (Manguinhos beach, $22^{\circ} 45^{\prime} \mathrm{S}, 41^{\circ} 55^{\prime} \mathrm{W}$ ), 28 specimens, 02/VI/2009, IBUFRJ-0734. Rio de Janeiro: Sepetiba Bay (Marambaia Island, $22^{\circ} 51^{\prime} \mathrm{S}, 43^{\circ} 57^{\prime} \mathrm{W}$ ), 61 specimens, 12/I/2004, IBUFRJ-0735. São Paulo: São Sebastião (Cabelo Gordo beach, $\left.23^{\circ} 49^{\prime} \mathrm{S}, 4^{\circ} 25^{\prime} \mathrm{W}\right), 20$ specimens, $17 / \mathrm{VI} / 2002$, IBUFRJ- 1257. Paraná (Mel Island, $25^{\circ} 30^{\prime} \mathrm{S}, 48^{\circ} 18^{\prime} \mathrm{W}$ ), 17 specimens, 12/VI/ 2007, IBUFRJ-1258.

Remarks: The material referred to $S$. chilensis is quite similar to the original description by HARTMANN-SCHRÖDER (1962) and the redescription by BLAKE (1983). Specimens here observed 
presented hooded hooks with a bridge connecting two small teeth positioned side-by-side above the main fang. This character state was also observed by BLAKE (1983) who considered it to be bidentate, as in the original description, even though it appears as unidentate in lateral view.

Distribution: Pacific Ocean: Chile; Atlantic Ocean: Brazil (São Paulo and Rio de Janeiro).

\section{Scolelepis lighti Delgado-Blas, 2006}

Scolelepis lighti Delgado-Blas, 2006: 85, fig. 5. Scolelepis lighti; Santos et al., 2008: 5, figs 1-2.

Material examined: 30 specimens: Brazil, Bahia: Morro de São Paulo (Dois Irmãos beach, 1755'S, 39²4'W), 17/VIII/ 2010, IBUFRJ-1262.

Remarks: The material here referred to $S$. lighti approximates the original description of Delgado-Blas (2006). However, whereas specimens described by the former author present neuropodial postchaetal lamellae notched in chaetiger 23, in our specimens it was observed in chaetiger 25. Records of this species on the Brazilian Coast was restricted to the north-eastern coast (Paraíba), now being extended to the eastern coast (Bahia).

Distribution: Gulf of Mexico; Atlantic Ocean: Brazil (Bahia and Paraíba).

\section{Scolelepis squamata (Müller, 1806)}

Lumbricus squamatus Müller, 1806: 39.

Lumbricus cirratulus Delle Chiaje, 1828: 177; Quatrefages, 1865: 506. Scolelepis squamosa Blainville, 1828: 492.

Malacoceros longirostris Quatrefages, 1843: 13; 1865: 443.

Scolecolepis squamata Michaelsen, 1897: 45.

Scolelepis squamata; Pettibone, 1963: 92; Foster, 1971: 59, figs 118-131; Light, 1977: 73-65; 1978: 105-108; Kinner \& Maurer, 1978: 215; Gillandt, 1979: 47-48; Bolivar \& Lana (1986) (in part); Delgado-Blas, 2006: 78, fig. 1.

Scolelepis agilis; Fauchald, 1973: 25.

Scolelepis goodbodyi; Rocha, Radashevsky \& Paiva, 2009: 102, fig. 1 (in part).

Material examined: 103 specimens: Brazil, Pernambuco: Recife (Boa Viagem beach, $8^{\circ} 07^{\prime} \mathrm{S}, 34^{\circ} 53^{\prime} \mathrm{W}$ ), 3 specimens, 17/ VI/2008, IBUFRJ-1260. Pernambuco: Recife (Porto de Galinhas, $\left.8^{\circ} 50^{\prime} \mathrm{S}, 35^{\circ} 07^{\prime} \mathrm{W}\right), 30$ specimens, 22/IX/2010, IBUFRJ-1252.

Rio de Janeiro: Ilha Grande Bay (Dois Rios beach, $23^{\circ} 11^{\prime} \mathrm{S}$, $\left.44^{\circ} 11^{\prime} \mathrm{W}\right), 70$ specimens, 10/VII/2005, IBUFRJ-1259.

Remarks: Scolelepis squamata has a problematic taxonomic status. Petтibone (1963) synonymized several species within $S$. squamata, including Nerine agilis Hartman, 1941, Lumbricus cirratulus Quatrefages, 1865, Nerine minuta Treadwell, 1939 and Nerinides goodbodyi Jones, 1962. Foster (1971) and Light (1977, 1978), while corroborating such synonymies, pointed out the intra-specific variability of characters such as the number of neuropodial hooded hooks, the presence or absence of notopodial hooded hooks, and the shape of the neuropodial postchaetae lamellae. This variability gives rise to an overlap of character states among $S$. squamata and other similar species, such as $S$. goodbodyi and mainly $S$. chilensis, leading to taxonomic confusion. However, in $S$. chilensis, the branchiae on the anterior segments are less fused with the notopodial postchaetal lamellae, about $1 / 2$ against $2 / 3$ in $S$. squamata. The material from Dois Rios beach, Ilha Grande Bay, collected on July 10, 2005, and included by Rocha et al. (2009) in S. goodbodyi, is here considered as $S$. squamata, due to the absence of glandular cells in the midline of the branchiae, a diagnostic character of $S$. goodbodyi.

Distribution: Atlantic Ocean: Barbados, Brazil, Central America, east coast of North America, England, Mozambique, Scotland to South Africa, Senegal; Mediterranean; Pacific Ocean: North Pacific.

\section{Scolelepis andradei Delgado-Blas, Díaz \& Liñero-Arana, 2009}

Figs 1-14

Scolelepis andradei Delgado-Blas, Díaz \& Liñero-Arana, 2009: 1, fig. 1.

Material examined: 71 specimens: Brazil, Paraná: Pontal do Paraná (Pontal do Sul beach, 23³4'S, 48²0’W), 09/IX/2009, IBUFRJ-1263.

Description: 31 complete specimens, $14-25 \mathrm{~mm}$ long, 1.0$1.4 \mathrm{~mm}$ wide at chaetiger 2,61-101 chaetigers and 40 incomplete specimens, 4-17 mm long, 0.9-1.3 mm wide, 46-80 chaetigers. Color in alcohol: white-brownish.

Prostomium conical, elongated and posteriorly triangular, twice longer than wide (Figs 7-8). Caruncle extending posteriorly to chaetiger 2 . Peristomium forming well-developed lateral wings involving the prostomium. Two pairs of brown eyes arranged in a transverse row. Central eyes rounded and lateral ones reniform. Spotted reddish pigmentation bands above eyes. Palps short (Figs 1-2), extending up to chaetiger 12 carrying two longitudinal ciliary bands.

Parapodia of chaetiger 1 well-developed, notopodial postchaetal lamellae triangular and neuropodial postchaetal lamellae subtriangular with capillary chaetae in both rami (Fig. 9). Notopodial postchaetal lamellae elongated and oval from chaetiger 2 with a slight ripple on medium body chaetigers (Fig. 10).

Branchiae present from chaetiger 2, tapered and elongated with a band of cilia in the inner side, more developed in the anterior and middle part of the body, becoming smaller from chaetiger 35 (Fig. 3). Branchiae partially fused, about 1/2, to notopodial postchaetal lamellae until about chaetiger 25 , thereafter, become fused only to basal lamellae (Fig. 11).

Neuropodial postchaetal lamellae subtriangular from chaetigers 1-3, becoming rounded from chaetigers 4-23 (Fig. 4 ), developing a slight notch in chaetiger 24 , becoming deeper, 

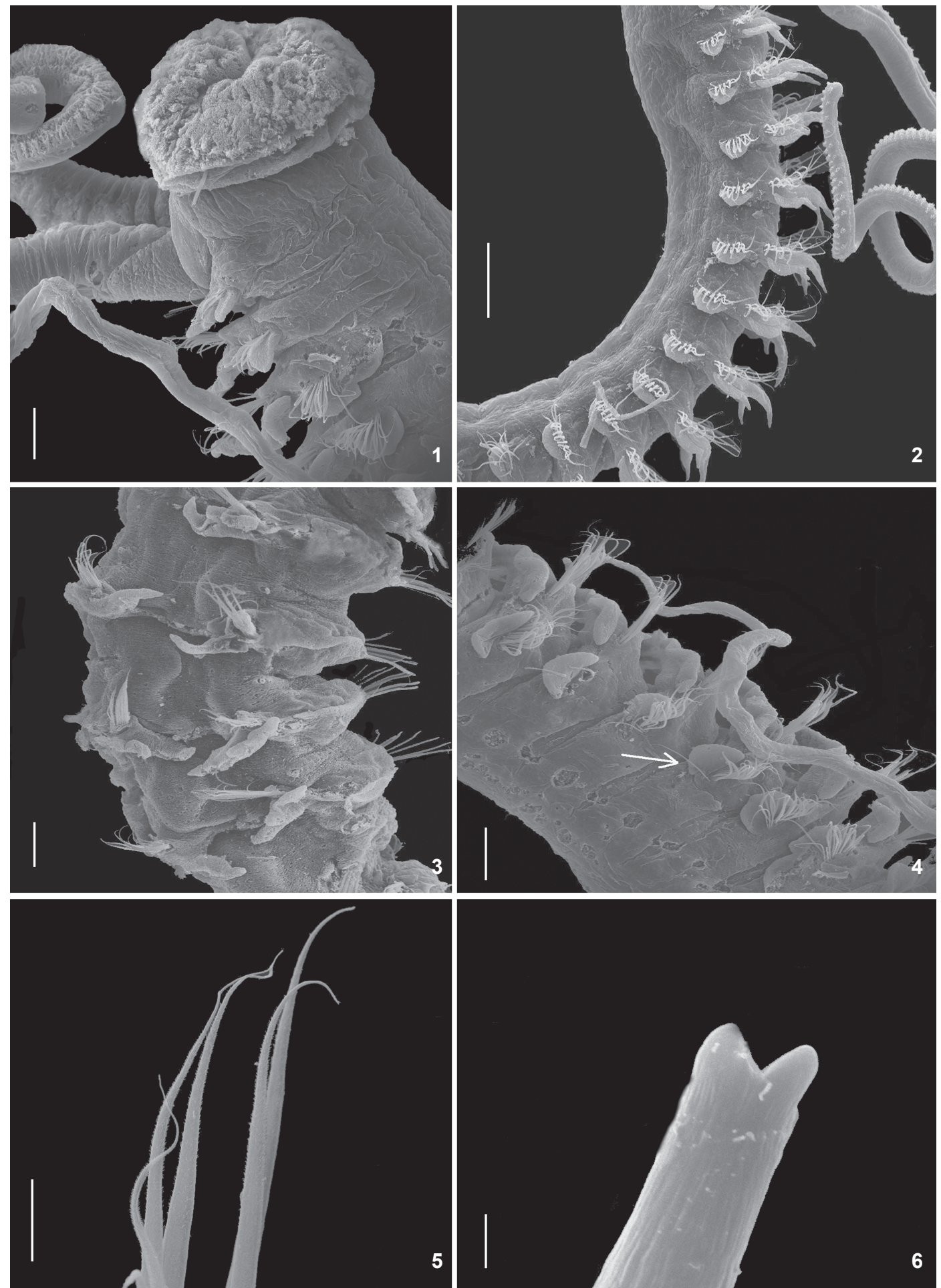

Figures 1-6. Scolelepis andradei: (1) Anterior end, ventral view, with palps; (2) segments 2-12, showing notopodial postchaetal lamellae fused to branchiae, and neuropodial postchaetal lamellae entire, rounded; (3) posterior segments showing the reduction of the branchiae; (4) chaetigers 2-7, showing neuropodial postchaetal lamellae entire, subtriangular; (5) capillaries chaetae of chaetiger 48; (6) neuropodial hooded hook of chaetiger 29 , hood removed. Scales bar: 13-16=200 $\mu \mathrm{m}, 17=30 \mu \mathrm{m}, 18=100 \mu \mathrm{m}$. 
dividing lamellae into separate lobes in chaetiger 25 (Fig. 12). From chaetiger 31 the upper lobe becomes broader and triangular and the lower, smaller and rounded. Neuropodia of anterior chaetigers with capillary chaetae (Fig. 6) only being accompanied by limbate ones after chaetiger 20 .

Neuropodial hooded hooks present from chaetiger 23 onwards with 6-8 per neuropodia, extending to the last chaetiger. Hooded hooks have one or two smaller apical teeth positioned side by side above the main fang (Figs 5-13). Notopodial hooded hooks absent. Pygidium shaped as a rounded cushion (Fig. 14).

Remarks: The material here referred to as $S$. andradei resembles the original description of Delgado-Blas et al. (2009), but differs in the emergence of the hooded hooks (from chaetiger 26 in this study, 28 in the original description). Another difference is the number of accessory teeth in the original description of $S$. andradei, one in the original description and one or two in specimens from Brazil. S. andradei is similar to $S$. goodbodyi, inhaving a well-developed peristomium and elongated branchiae with a tapered end, besides possessing uniand bidentate neuropodial hooded hooks, but lacking notopodial ones. Notwithstanding this, $S$. andradei differs from S. goodbodyi by having short palps and lacking gland-cells on the branchiae. Furthermore, the notopodial postchaetal lamellae of the anterior and medium body-regions are complete and with slight ripples. S. andradei is also similar to $S$. lighti in the
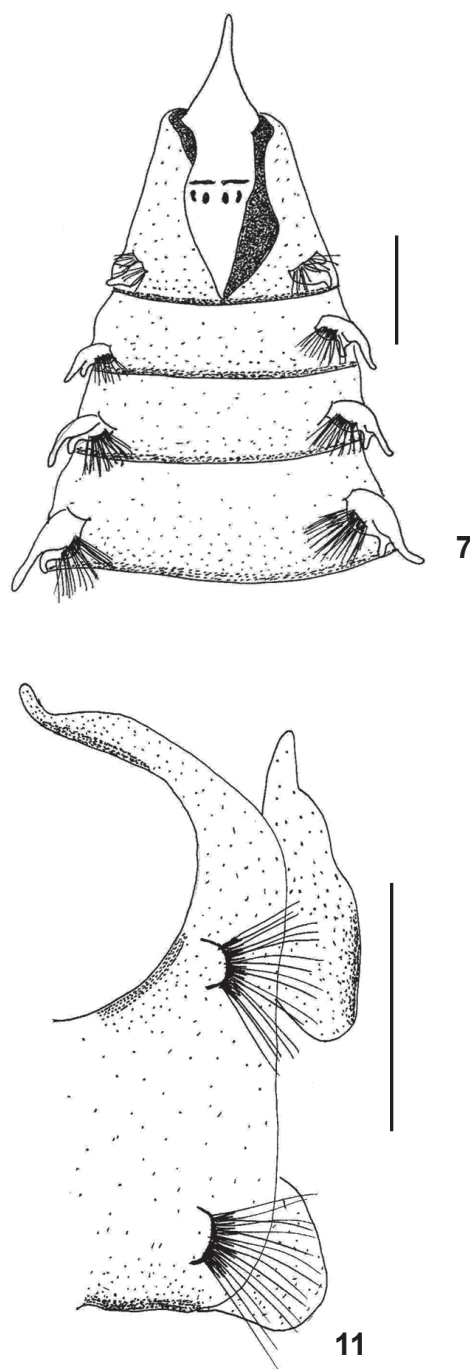

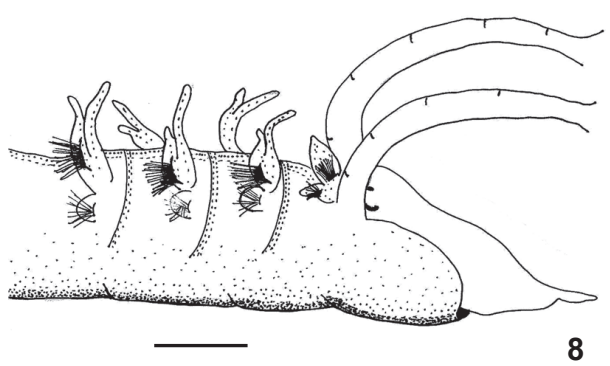

8
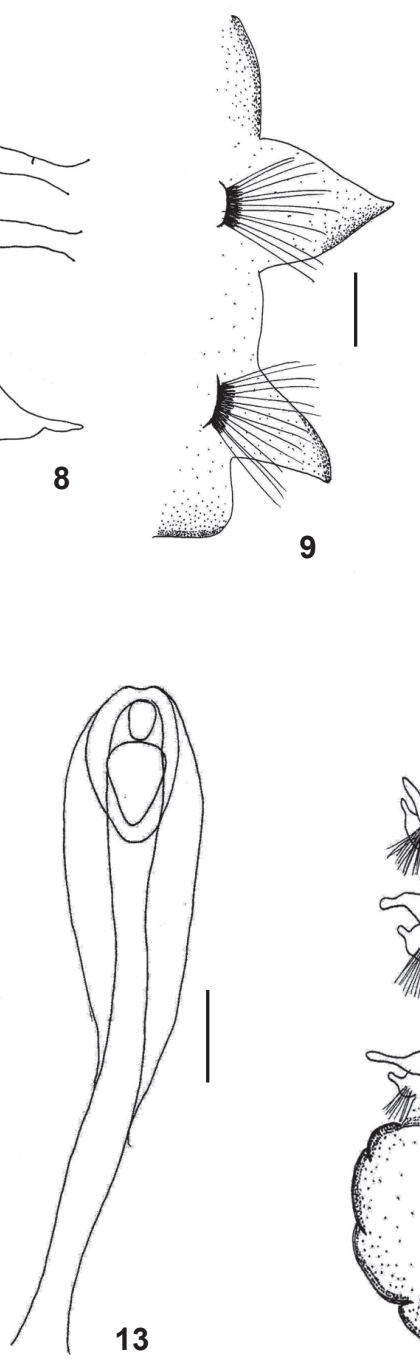

Figures 7-14. Scolelepis andradei: (7) anterior region, dorsal view; (8) anterior region, lateral view; (9) parapodia of chaetiger 1; (10) parapodia of chaetiger 2; (11) parapodia of chaetiger 5; (12) parapodia of chaetiger 25; (13) neuropodial hooded hook of chaetiger 39; (14) pygidium dorsal view. Scales bar: 19-20 = $750 \mu \mathrm{m}, 21-26=100 \mu \mathrm{m}, 22-24=200 \mu \mathrm{m}$. 

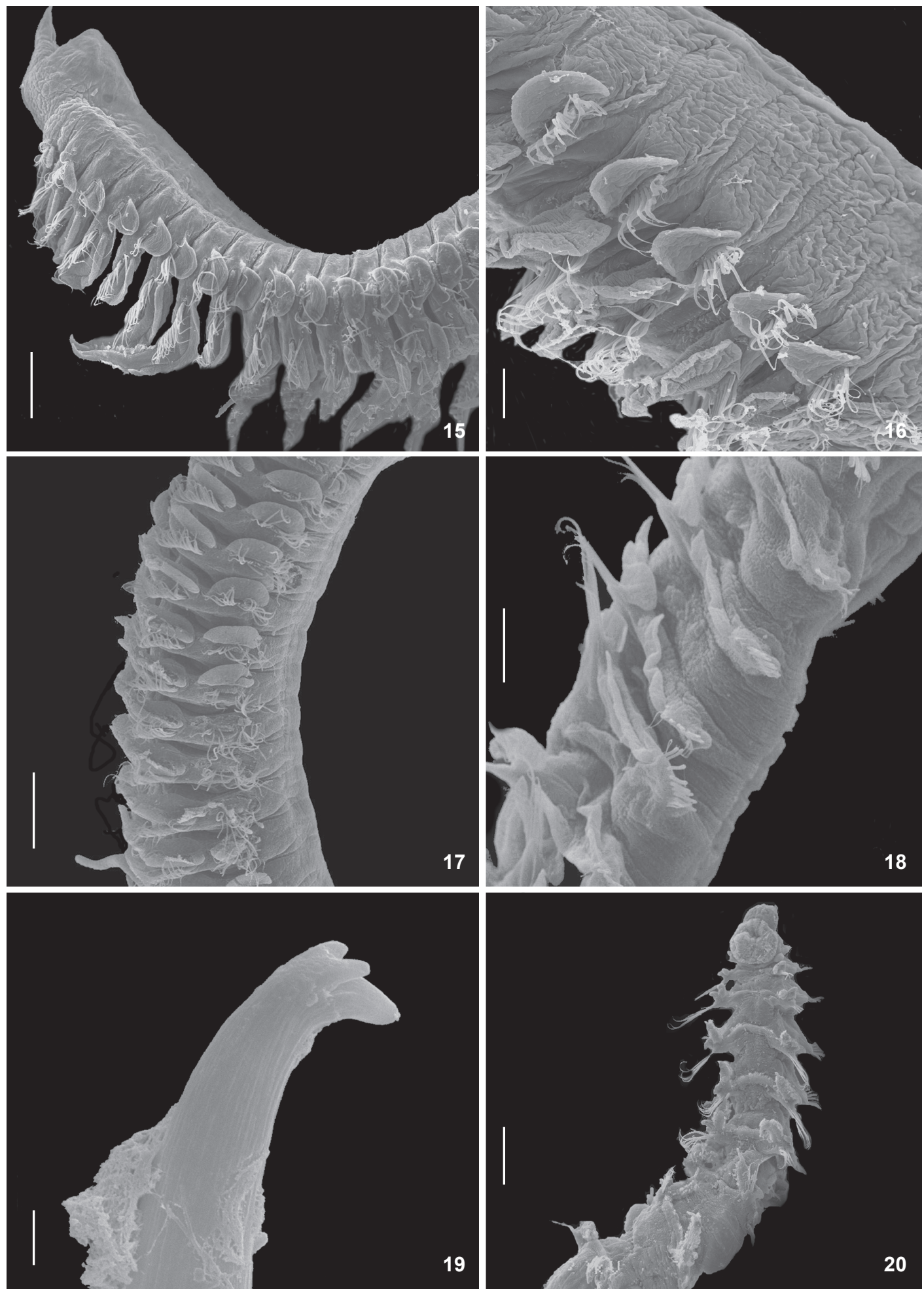

Figures 15-20. Scolelepis acuta: (15) anterior end, lateral view, palps missing; (16) chaetigers 2-5, showing neuropodial postchaetal lamellae entire, rounded; (17) segments 10-20; (18) chaetigers 47-51 with smaller branchiae; (19) neuropodial hooded hooks of chaetiger 36 , hood removed; (20) posterior end, showing small cushion-like pygidium. Scales bar: $27-31=200 \mu \mathrm{m}, 32=100 \mu \mathrm{m}$. 
shape of the prostomium in having a well-developed peristomium, and by the degree of fusion of the branchiae with the notopodial postchaetal lamellae, but differs by the anterior and mid-region branchiae tapering at the distal end and the subtriangular neuropodial postchaetal lamellae from chaetigers 1 to 3 .

Distribution: Caribbean Sea: Venezuela; Atlantic Ocean: Brazil (Paraná).

\section{Scolelepis acuta (Treadwell, 1914)}

Figs 15-28

Spio acuta Treadwell, 1914: 199-201, figs 14-20.

Scolelepis acuta; Delgado-Blas, 2006: 79, fig. 2.

Material examined: 69 specimens: Brazil, Rio de Janeiro: Sepetiba Bay (Marambaia Island, 22 $2^{\circ} 51^{\prime} \mathrm{S}, 43^{\circ} 57^{\prime} \mathrm{W}$ ), 69 specimens, 12/I/2004, IBUFRJ-1261.
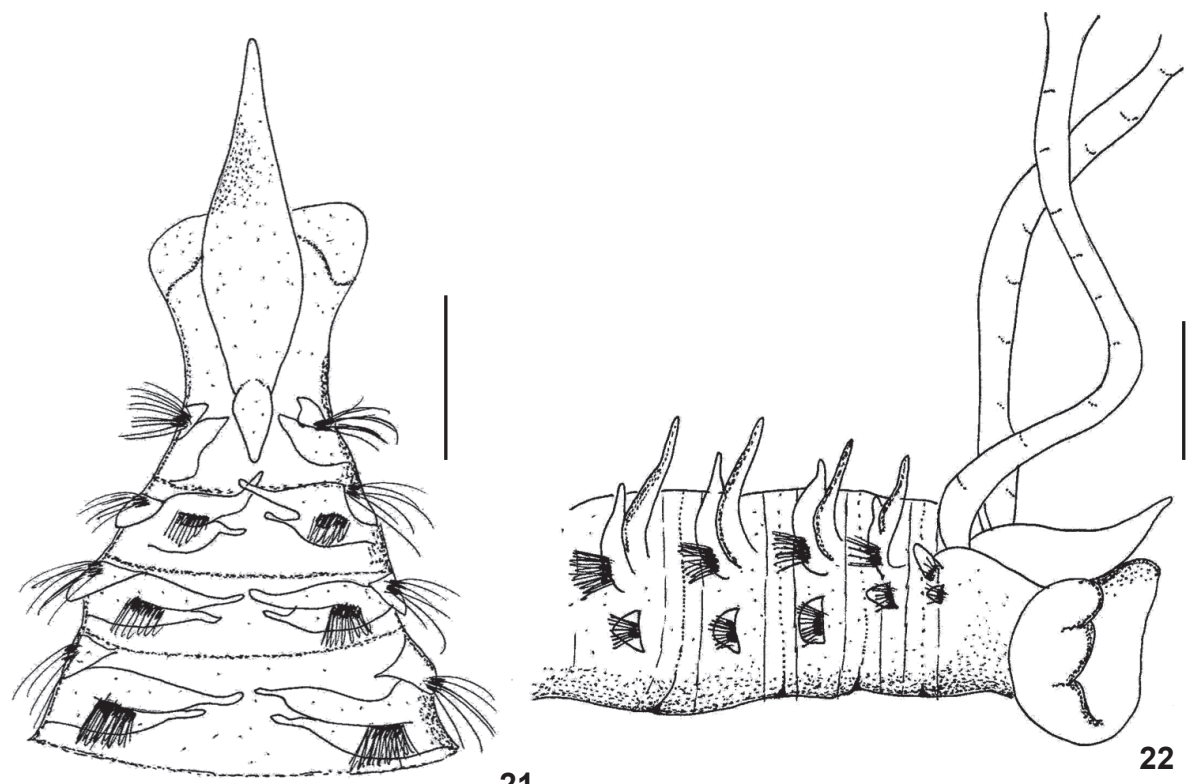

21
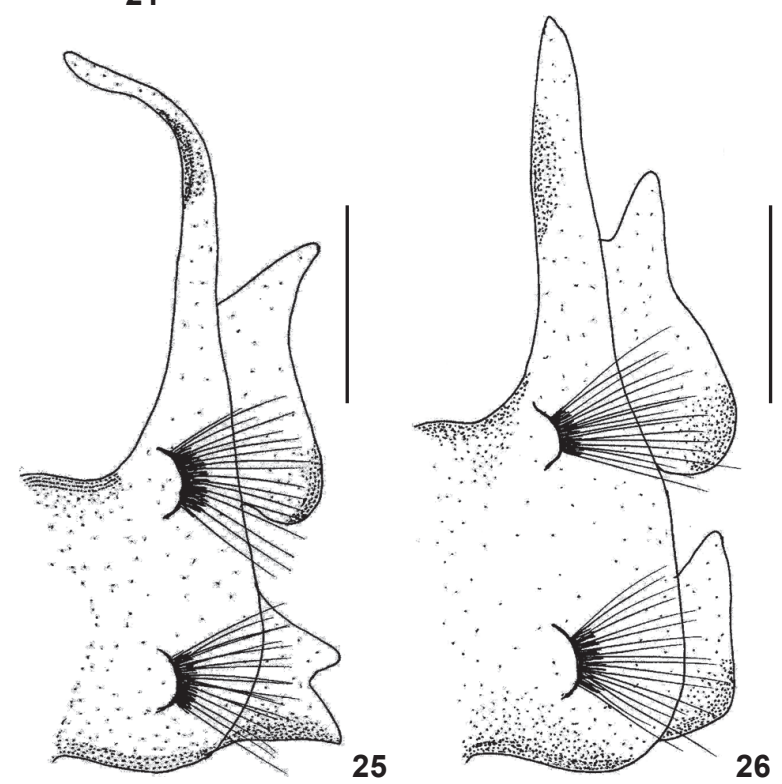
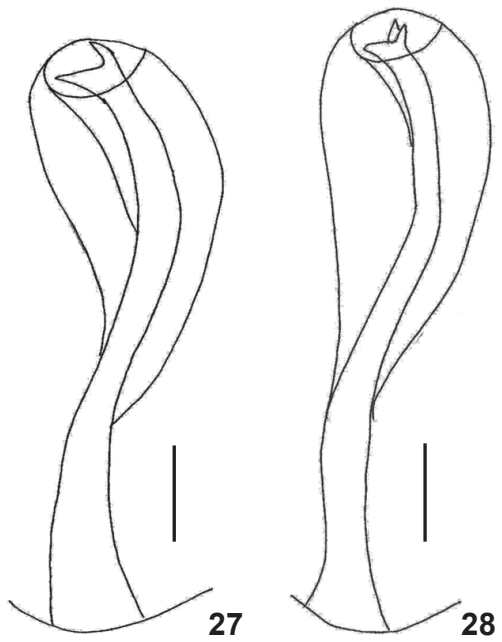

Figures 21-28. Scolelepis acuta : (21) anterior region, dorsal view; (22) anterior region, lateral view; (23) parapodia of chaetiger 1; (24) parapodia of chaetiger 2 ; $(25)$ parapodia of chaetiger $34 ;(26)$ parapodia of chaetiger 59; $(27-28)$ neuropodial hooded hooks of chaetigers 32-36. Scales bar: $33-34=800 \mu \mathrm{m}, 35=100 \mu \mathrm{m}, 36-38=200 \mu \mathrm{m}, 39-40=10 \mu \mathrm{m}$. 
Description: 28 complete specimens, 9-15 mm long, 0.8$1.0 \mathrm{~mm}$ wide at chaetiger 2 , with $60-80$ chaetigers and 41 incomplete specimens, 4-12 $\mathrm{mm}$ long, 0.7-1.1 $\mathrm{mm}$ wide, with 46-61 chaetigers. Color in alcohol dark brown.

Prostomium anteriorly acute, posteriorly rounded, two times longer than wide (Figs 21-22). Caruncle short extending posteriorly to chaetiger 1 . Peristomium short forming well-developed lateral wings involving the prostomium (Fig. 15). Eyes not visible. Palps extending up to chaetiger 11, provided with two ciliary bands.

Parapodia of chaetiger 1 well-developed with notopodial postchaetal lamellae triangular and neuropodial postchaetal lamellae rounded, with capillary chaetae in both rami (Fig. 23). Notopodial postchaetal lamellae oval with distal finger-like endings on anterior chaetigers and square-shaped after chaetiger 30 , becoming gradually smaller in the posterior chaetigers.

Branchiae present from chaetiger 2, with elongated and tapered end, especially in the anterior and middle regions of the body and carrying bands of cilia in their inner side (Figs 16-17). Branchiae partially fused, by about $1 / 2$, to notopodial postchaetal lamellae until about chaetiger 29 , thereafter, become fused only in the basal lamellae (Fig. 18).

Neuropodial postchaetal lamellae rounded on anterior chaetigers, developing a slight notch in chaetiger 22, becoming deeper, dividing lamellae into separate lobes in chaetiger 25 (Figs 24-25). The lower lobe is triangular and the upper rounded with elongated tip (Fig. 26). Neuropodia of anterior chaetigers with capillaries chaetae only, accompanied by limbate after chaetiger 28. Chaetae similar in shape in both rami (noto- and neuropodia).

Neuropodial hooded hooks present from chaetiger 27, up to seven per neuropodia, extending to the last chaetiger. Hooded hooks with one or two smaller apical teeth positioned side by side above the main fang (Figs. 19, 27, 28). Notopodial hooded hooks absent. Pygidium shaped as a rounded cushion (Fig. 20).

Remarks: The material here referred to $S$. acuta fits the original description of TREADWELl (1914), as well as the redescription by Delgado-Blas (2006). Scolelepis acuta resembles $S$. squamata in the shape of the hooded hooks and the presence of small notches on neuropodial postchaetal lamellae from the median and posterior regions of the body. Such similarity led Pettibone $(1963)$ and Light $(1977,1978)$ to consider it as a junior synonym of S. squamata. However, S. acuta differs in the, peristomium forming well-developed lateral wings, short palps and elongated branchiae with very sharp edges. S. squamata, by contrast, has theperistomium forming undeveloped lateral wings, long palps extending up to chaetiger 22, and bilobed notopodial postchaetal lamellae on the anterior chaetigers. We have also observed some similarities between $S$. acuta and $S$. goodbodyi such as the shape of the notopodial and neuropodial postchaetal lamellae of parapodia 1 , the extension of the prostomium, and the shape of the neuropodial postchaetal lamellae along the body. This is the first record of the species found in the Atlantic Ocean, a pattern that could suggest that this is an invasive species (exotic), since it was found in a bay were a large port with intense international traffic (Port of Itaguaí, state of Rio de Janeiro) is located. Nevertheless, we have no further information that could corroborate this hypothesis.

Distribution: Pacific Ocean: USA (California); Atlantic Ocean: Brazil (Rio de Janeiro).

\section{ACKNOWLEDGMENTS}

We thank all those who helped in collecting the material: Bruna Faro, Danielle Vilela, Victor Seixas, Ricardo Bastos, Nury Eunice, Fábio MacCord, Christine Ruta, Vasily I. Radashevsky, and Gabriela Neves. We thank CNPq and FAPERJ for providing financial support and $\mathrm{CNPq}$ for the fellowship awarded to the second author.

\section{LITERATURE CITED}

Amaral, A.C.Z.; S.A.H. Nallin; T.M. Steiner; T.O. Forroni \& D. Gomes Filho. 2012. Catálogo das espécies de Annelida Polychaeta do Brasil. Campinas, available online at: http:/ /www.ib.unicamp.br/museu_zoologia/files/lab_museu_zoologia/Catalogo_Polychaeta_Amaral_et_al_2012_0.pdf [Accessed: 10.V.2012].

Blainville, H. DE. 1828. Dictionnaire des Sciences Naturelles 47: $368-501$

BLAKE, J.A. 1983. Polychaetes of the family Spionidae from South America, Antarctica, and adjacent seas and islands. Antarctic Research Book Series 39: 205-288.

BlaKe, J.A. 1996. Family Spionidae Grube, 1850, including a review of the genera and species from California and a revision of the genus Polydora Bosc, 1802, p. 81-223. In: J.A. Blake; B. Hilbig \& P.H. Scott (Eds). The Annelida, Part 3. Polychaeta: Orbiniidae to Cossuridae, Taxonomic Atlas of the Benthic Fauna of the Santa Maria Basin and the Western Santa Barbara Channel. Santa Barbara, Santa Barbara Museum Natural History, vol. 6.

Blake, J.A. 2006. Spionida, p. 565-638. In: G. Rouse \& F. Pleijel (Eds). Reproductive Biology and Phylogeny of Annelida. Enfield, Science Publishers, vol. 4.

Blake, J.A. \& P.L. Arnofsky. 1999. Reproduction and larval development of the spioniform Polychaeta with application to systematics and phylogeny. Hydrobiologia 402: 57-106.

Bolivar, G.T.A. \& P.C. Lana. 1986. Spionidae (Annelida: Polychaeta) do litoral do Estado do Paraná. Nerítica 1 (3): 107-148.

Delgado-Blas, V.H. 2006. Partial revision of Scolelepis (Polychaeta: Spionidae) from the Grand Caribbean region, with the description of two new species and a key to species recorded in the area. Contributions to Zoology 75 (1/2): 75-97.

Delgado-Blas, V.H.; O.F.D. Diaz \& I. Liñero-Arana. 2009. New record and new species of Scolelepis (Polychaeta: Spionidae) 
from the Venezuelan, Caribbean. Journal of Marine Biological Association of the United Kingdom 88: 1-5.

Delle Chiaje, S. 1828. Memorie sulla Storia e Notomia degli Animali sense vertebre del Regno di Napoli. Napoli 3: 1-232.

Eibye-Jacobsen, D. \& A.G. SoARes. 2000. New records of Scolelepis (Polychaeta: Spionidae) from the sandy beaches of Madagascar, with the description of a new species. Bulletin of Marine Science 67 (1): 571-586.

Fauchald, K. 1973. Polychaetes from Central American sandy beaches. Bulletin of the Southern California Academy of Sciences 72 (1): 19-31.

Foster, N.M. 1971. Spionidae (Polychaeta) of the Gulf of Mexico and the Caribbean Sea. Studies on the Fauna of Curacao and other Caribbean Islands 129: 1-183.

Gillandt, L. 1979. Zur Systematic, Autokologie und Biologie der Polychaeten des Helgolander Felslitorals. Mitteilungen aus dem Hamburgisch en Zoologischen Museum und Institut 76: 19-73.

HARTMANN-SCHRÖDER, G. 1962. Die polychaeten des Eulitorals. In Zur Kenntnis des Eulitorals der Chilenischen Pazifikküste und der Argentinischen Küste, südpatgoniens unter besonderer Berücksichtigung der Polychaeten und Ostracoden. Mitteilungen Hamburgisches Zoologisches Museum und Institut 60: 57-167.

ImajIMA, M. 1992. Spionidae (Annelida, Polychaeta) from Japan, 8. The genus Scolelepis. Bulletin of the National Science Museum Tokyo 18: 1-34.

JoNES, M.L. 1962. On some polychaetous annelids from Jamaica, the West Indies. Bulletin of the American Museum of Natural History 124 (5): 169-212.

Kinner, P. \& Maurer, D. 1978. Polychaetous annelids of the Delaware Bay region. Fishery Bulletin 76 (1): 209-224.

Lana, P.C.; C.S.G. Santos; A.R.S. Garrafoni; V.M. Oliveira \& V. Radashevsky. 2006. Checklist of polychaete species from Paraná State (Southern Brazil). Check List 2: 30-63.

Light, W.J. 1977. Spionidae (Annelida: Polychaeta) from San Francisco Bay, California: A revised list of nomenclatural changes, new records, and comments on related species from the northeastern Pacific Ocean. Proceedings of the Biological Society of Washington 90: 66-88.

Light, W.J. 1978. Spionidae (Polychaeta: Annelida), p. In: W.L. Lee (Ed.). Invertebrates of the San Francisco Bay Estuary
System. Pacific Grove, Boxwood Press.

MACCORD, F.S. \& A.C.Z. AmARAL. 2005. Morphometric analysis of two species of Scolelepis (Polychaeta: Spionidae). Journal of Marine Biology 84: 769-784.

MACIOLEk. N.J. 1987. New species and records of Scolelepis (Polychaeta: Spionidae) from the east coast of North America. Proceedings of the Biological Society of Washington 7: 16-40.

Michaelsen, W. 1897. Die Polychaeten fauna der deutschen Meer, einschliesslich der benachbargen und verbindenden Gebiete. Wissenshaftliche Meeresuntersuchugen deutsch Meere 2: 1-216.

Müller, O.F. 1806. Zoologia Danica seu Animalium Daniae et Norvegiae rariorum ac minus notorum, Descriptiones et Historia. Havniae, 160 pp.

Petribone, M.H. 1963. Revision of some genera of polychaete worms of the family Spionidae, including the description of a new species of Scolelepis. Proceedings of the Biological Society of Washington 76: 89-104

Quatrefages, J.A. 1843. Description de quelques espèces nouvelles d'Annélides errantes recueilles sur les côtes de La Manche. Magasin Zoologique Paris 2 (5): 1-116.

Quatrefages, J.A. 1865. Histoire naturelle des Anneles marine et d'eau douce. Annelides et Gephyriens, $588 \mathrm{pp}$.

Rocha, M.B.; V. Radashevsky \& P.C. Paiva. 2009. Espécies de Scolelepis (Polychaeta, Spionidae) de praias do Estado do Rio de Janeiro, Brasil. Biota Neotropica 9 (4): 101-108.

Santos, A.S.; D.A. Costa \& M.L. Christoffersen. 2008. First record of Scolelepis (Scolelepis) lighti along the Brazilian coast. Journal of Marine Biological Association 2: 1-5.

Treadwell, A.J. 1914. Polychaetous annelids of the Pacific coast in the collection of the Zoological Museum of the University of California. University of California Publications in Zoology 13: 175-234.

Williams, J.D. 2007. New records and description of four new species of spionids (Annelida: Polychaeta: Spionidae) from the Philippines: the genera Dispio, Malacoceros, Polydora, and Scolelepis, with notes on the palp ciliation patterns of the genus Scolelepis. Zootaxa 1459: 1-35.

Zhou, H.; J. WeIweI \& L. XINZHeng. 2009. A new species of Scolelepis (Polychaeta: Spionidae) from sandy beaches in China, with a review of Chinese Scolelepis species. Zootaxa 2236: 37-49.

Submitted: 07.XII.2011; Accepted: 21.V.2012.

Editorial responsibility: Paulo da Cunha Lana 